\title{
Indian and Chinese Traditional Medicine on COVID-19: A Review and Perspective
}

\author{
Salvilla, Remi Charlene M. ${ }^{1,2,3}$, Faller, Erwin M. ${ }^{1,2,3,4}$ \\ ${ }^{1}$ School of Pharmacy, Centro Escolar University, Manila, Philippines \\ ${ }^{2}$ Pharmacy Program, University of San Agustin, Iloilo City, Philippines \\ ${ }^{3}$ Graduate School, Centro Escolar University, Manila, Philippines \\ ${ }^{4}$ Pharmacy Department, San Pedro College, Davao City, Philippines \\ DOI: 10.29322/IJSRP.11.08.2021.p11612 \\ http://dx.doi.org/10.29322/IJSRP.11.08.2021.p11612
}

\begin{abstract}
The coronavirus has spread around the world that it was declared a pandemic in March 2020. Millions of people have been infected, and even died because of it. Researchers and pharmaceutical companies have been working on vaccines and treatments to curb the infection. People have looked into the utilization of traditional medicines as a complementary and preventive therapy for COVID-19. Indian and Chinese traditional medicines contain ingredients that were found to have potential as complements to COVID-19 therapy. This report gives a review and perspective on the use of Indian and Chinese traditional medicine for COVID-19. The perspective is an opinion of the authors regarding the use of traditional medicine as a prevention and complementary therapy against COVID-19
\end{abstract}

Index Terms Chinese Traditional Medicine, Indian Traditional Medicine, COvid-19, Review, Perspective, Coronavirus outbreak

\section{Introduction}

The coronavirus outbreak came to light on December 2019 when China informed the World Health Organization of a cluster of cases of pneumonia of an unknown cause in Wuhan City in Hubei Province [1]. Subsequently the disease spread to more Provinces in China, and to the rest of the world. The WHO declared it a pandemic in March 2020 [2]. Since then, multiple variants of the virus have been reported. Scientists are looking for ways to detect, prevent, and cure the disease. Because of the time that it will take for the medicines and vaccines to be manufactured, people have turned to herbal medicines to combat COVID-19 [3]. The most common traditional medicine systems are the Indian and Chinese traditional medicine systems [4]. In India, Ayurveda is considered not just as an ethnomedicine but also as a complete medical system that takes in to consideration physical, psychological, philosophical, ethical and spiritual well being of mankind. It lays great importance on living in harmony with the universe and harmony of nature and science. The Chinese Traditional Medicine philosophy on the other hand focuses on Qi and proposes that everything is composed of the five elements: fire, earth, metal, water and wood.

In this paper, articles relating to traditional medicines are searched, collected, and reviewed. The perspective is an opinion of the author regarding the use of traditional medicine as a prevention and complementary therapy against COVID-19.

\section{Method}

In this review and perspective, data related to COVID-19 were searched and collected. The review was conducted utilizing journal databases such as BMJ Global Health, Researchgate,
Elsevier, Google Scholar, Pubmed, and The Lancet. The articles were then reviewed and interpreted. The search terms used included: Coronavirus, COVID-19, history, etiology, signs, symptoms, management for COVID-19, antiviral activities of herbs against influenza, SARS-CoV-1, and SARS-CoV-2. There was no limitation on the language and year of studies. The chosen articles were reviewed and interpreted by the authors. The perspective is an opinion of the authors regarding the use of herbs in Indian and Chinese traditional medicines as a prevention and complementary therapy against COVID-19.

\section{History, Etiology, Signs and Symptoms.}

It was Dr. Li Wenliang, an ophthalmologist in Wuhan, China who reported the first case of the pneumonia with an unknown cause in 2019 [5]. The Huanan seafood market in Wuhan was suspected to be associated with the early cases of COVID-19 infected patients, as wild-animal trading occurs in the area [7]. The bat, sold as food in the Wuhan market, was initially assumed to be the intermediate host for the disease to emerge in humans. Phylogenetic analysis showed that the virus fell within the Betacoronavirus genus, and was genetically distinct from SARSCoV [8].

In January 13, 2020, the first 2019-nCoV infection outside of China was reported in Thailand [9]. Since then, cases of the 2019nCoV infection were reported in Japan [10], Korea [11], Singapore [12], Vietnam [13], and in the USA [14].

A study by Huang, et.al, showed that the first 41 admitted hospital patients identified as having the $2019 \mathrm{nCoV}$ infection in Wuhan exhibited common symptoms at onset of illness such as fever, cough, myalgia or fatigue, with less common symptoms such as 
headache, haemoptysis, sputum production, and diarrhea. All 41 patients exhibited pneumonia with abnormal findings on chest CT scans [15]. These clinical features were seen to resemble

\begin{tabular}{|c|c|c|c|}
\hline & Scientific Name & $\begin{array}{l}\text { Local name } \\
\text { in Tamil }\end{array}$ & Part used \\
\hline 1 & $\begin{array}{l}\text { Zingiber } \\
\text { officinale L. }\end{array}$ & Sukku & Rhizome \\
\hline 2 & Piper longum L. & Thippili & Fruit \\
\hline 3 & $\begin{array}{l}\text { Syzygium } \\
\text { aromaticum L. }\end{array}$ & Ilavankam & $\begin{array}{l}\text { Flower } \\
\text { bud }\end{array}$ \\
\hline 4 & $\begin{array}{l}\text { Tragia } \\
\text { involucrate L. }\end{array}$ & $\begin{array}{l}\text { Sirukanchori } \\
\text { ver }\end{array}$ & Root \\
\hline 5 & $\begin{array}{l}\text { Anacyclus } \\
\text { pyrethrum L. }\end{array}$ & $\begin{array}{l}\text { Akkirakaram } \\
\text { ver }\end{array}$ & Root \\
\hline 6 & $\begin{array}{l}\text { Hygrophilia } \\
\text { auriculate } \\
\text { Schumach } \\
\end{array}$ & $\begin{array}{l}\text { Neermulli } \\
\text { ver }\end{array}$ & Root \\
\hline 7 & $\begin{array}{l}\text { Terminalia } \\
\text { chebula Retz. }\end{array}$ & Kadukkai & Fruit rind \\
\hline 8 & $\begin{array}{l}\text { Justicia } \\
\text { adhatoda L. }\end{array}$ & Adathodai & Leaf \\
\hline 9 & $\begin{array}{l}\text { Coleus } \\
\text { aromaticus } \\
\text { Benth }\end{array}$ & Karpuravalli & Leaf \\
\hline 10 & $\begin{array}{l}\text { Costus } \\
\text { speciosus (J. } \\
\text { Koenig) Sm. }\end{array}$ & Koshtam & Root \\
\hline 11 & $\begin{array}{l}\text { Tinospora } \\
\text { cordifolia } \\
\text { (Thunb.) Miers }\end{array}$ & Seendhil & Stem \\
\hline 12 & $\begin{array}{l}\text { Clerondendron } \\
\text { serratum (L.) } \\
\text { Moon }\end{array}$ & Siruthekku & Root \\
\hline 13 & $\begin{array}{l}\text { Andrographis } \\
\text { paniculata } \\
\text { Burm. F.Nees }\end{array}$ & Nilavembu & $\begin{array}{l}\text { Whole } \\
\text { plant }\end{array}$ \\
\hline 14 & $\begin{array}{l}\text { Sida acuta } \\
\text { Burm.f. }\end{array}$ & $\begin{array}{l}\text { Vattathiruppi } \\
\text { ver }\end{array}$ & Root \\
\hline 15 & $\begin{array}{l}\text { Cyperus } \\
\text { rotundus L. }\end{array}$ & $\begin{array}{l}\text { Korai } \\
\text { kilangu }\end{array}$ & $\begin{array}{l}\text { Root } \\
\text { tuber }\end{array}$ \\
\hline
\end{tabular}

infections of SARS-CoV and MERS-CoV in 2003 and 2013, respectively $[16,17]$. WHO Mission to China issued a statement after its visit to Wuhan that there was evidence of human to human transmission, but that more investigations must be done to understand its extent of transmission [18]. A study on the aerodynamic analysis of the virus done by Liu, et.al., proposed that the virus may have the potential to be transmitted through aerosols [19].

By March, Europe became the epicenter of the pandemic, and COVID-19 was declared as a pandemic [20]. In May 2020, WHO reported and approximately 5 million confirmed cases of COVID19 and more than 30 thousand deaths worldwide [21]. Chest CT scans played a big role for detecting COVID-19 in the earlier days of infection in China [22]. However, the gold standard for diagnosis remains to be the reverse transcription polymerase chain reaction (RT-PCR) positive for the viral RNA [23].
Multiple variants of SARS-CoV-2 are emerging around the world. The Center for Disease Control (CDC) introduced a scheme that identifies variants of the virus [24]. This brings about a variety of concerns to the medical community, especially that of a new variant having the ability to resist vaccine-induced immunity.

Currently, there are 153 million people infected with COVID-19 with 89.6 million recoveries, and 3.2 million deaths [25-27].

Medicinal plants and COVID-19

While scientists are trying hard to develop new potential therapeutic strategies, consisting of monoclonal antibodies, vaccines, peptides, Interferon-based therapies, protease inhibitors, and small-molecule drugs to defeat the COVID-19 pandemic, people have turned to complementary and alternative medicines for the possible prevention and treatment of COVID-19 [28-31].

In India, the traditional medicine system is widely used to prevent and remedy diseases. This system dates back to prehistoric times and is considered as a custom. The system comprises of Ayurveda [32-33], Homeopathy [34-35], Siddha medicine [36], along with Kabasura kudineer [37-39], yoga [40,41], and naturopathy [42]. The Ministry of AYUSH published an advisory regarding the challenge of COVID-19, which included guidelines on different traditional medicine customs [43].

The kabasura kundineer is a traditional Siddha medicine which contains fifteen natural ingredients, ranging from root to the entire plant (Table 1). In an initial screening of the fifteen ingredients, the following were identified as present: alkaloids, carbohydrates, glycosides, cardiac glycosides, flavonoids, phenols, saponins, tannins, hydrolysable tanins, and terpenoids [44]. A study on 84 subjects in Vellore, India, found that a kabasura kundineer formulation showed preliminary evidence for protection and prophylactic effect in high-risk COVID-19 cases [45]. Another study utilizing a bioinformatics approach for drug repurposing, compounds found on the kabasura kundineer formulation showed promising inhibition in SARS-CoV-2 [46].

Table 1. The fifteen (15) ingredients of the kabasura kundineer [43-44] 
Traditional Chinese medicine (TCM) is thousands of years old and has always focused on Its basic concept is that a vital force of life, called Qi that surges through the body. Diseases and illnesses are caused by an imbalance to Qi. Texts in the Traditional Chinese Medicine system, such as Huang Di Nei Jing (The Yellow Emperor's Classic of Medicine), and Shang Han Za Bing Lun (Treatise on Cold-induced and Miscellaneous Diseases) have shown descriptions related to severe respiratory diseases [47-49]. Studies on traditional Chinese medicine have been made, seeing that the use of TCM is deeply ingrained in the Chinese culture and traditions [50-53].

Table 2. Common TCM ingredients suggested for COVID-19 [54]

\begin{tabular}{|c|l|l|l|}
\hline & Scientific name & Local name & Part used \\
\hline 1 & $\begin{array}{l}\text { Ephedrae sinica } \\
{[50,52]}\end{array}$ & Mahuang & Stem \\
\hline 2 & $\begin{array}{l}\text { Armeniacae semen } \\
\text { amarum [50] }\end{array}$ & Xingren & Seeds \\
\hline 3 & $\begin{array}{l}\text { Glycyrrhizae radix } \\
\text { et rhizome [50-51] }\end{array}$ & Gancao & $\begin{array}{l}\text { Root and } \\
\text { stem }\end{array}$ \\
\hline 4 & $\begin{array}{l}\text { Gypsum fibrosum } \\
{[50,52]}\end{array}$ & Shigao & $\begin{array}{l}\text { Mineral } \\
\text { substance }\end{array}$ \\
\hline 5 & Arecae semen [51] & Binlang & Nut \\
\hline 6 & $\begin{array}{l}\text { Magnoliae } \\
\text { officinalis } \\
\text { cortex[51] }\end{array}$ & Houpo & Bark \\
\hline 7 & Tsaoko fructus [51] & Cao guo & Fruit \\
\hline 8 & $\begin{array}{l}\text { Anemarrhenae } \\
\text { rhizome [51] }\end{array}$ & Zhimu & Rhizome \\
\hline 9 & $\begin{array}{l}\text { Dioscoreae rhizome } \\
{[51]}\end{array}$ & Shaoyao & Rhizome \\
\hline 10 & $\begin{array}{l}\text { Scutellariae radix } \\
{[51]}\end{array}$ & Huang qin & Root \\
\hline 11 & $\begin{array}{l}\text { Pinelliae rhizome } \\
{[52]}\end{array}$ & Ban xia & Tuber \\
\hline 12 & $\begin{array}{l}\text { Aurantii fructus } \\
\text { immaturus [52] }\end{array}$ & Zhishi & Fruit \\
\hline 13 & $\begin{array}{l}\text { Zingiberis rhizoma } \\
\text { recens [52] }\end{array}$ & Shengjiang & Rhizome \\
\hline 14 & $\begin{array}{l}\text { Chincona L., Raiatea } \\
{[53,54]}\end{array}$ & Jīnjī nà & Bark \\
\hline 15 & Curcuma longa [55] & Jiānghuáng & Root \\
\hline 16 & $\begin{array}{l}\text { Echinacea } \\
\text { purpurea [56] }\end{array}$ & Rhizomes \\
\hline & Zhu Ha & \\
\hline
\end{tabular}

\section{Conclusion:}

This publication is licensed under Creative Commons Attribution CC BY. http://dx.doi.org/10.29322/IJSRP.11.08.2021.p11612
COVID-19 is a problem the entire world is facing. Millions have been infected, and people have died because of it. The design and development of drugs and vaccines require elucidation of the mechanism of SARS-CoV-2. These processes take time, hence, people are going the "natural" way of curbing the spread of the coronavirus. Indian and Chinese traditional medicine are the most commonly used alternative therapy to curb COVID-19. Of the various herbal medicines used as ingredients in traditional Indian and Chinese medicine, current literature provides obvious evidence supporting herbal medicines and traditional medicines as potential effective antivirals and as preventive agents against COVID-19. Hence, these are possible complementary or adjunct preventive therapy for COVID-19. However, these hypotheses require experimental validation in SARS-Cov-2 infection models and COVID-19 patients.

\section{REFERENCES:}

1. Singhal T. (2020). A Review of Coronavirus Disease-2019 (COVID19). Indian journal of pediatrics, 87(4), 281-286. https://doi.org/10.1007/s12098-020-03263-6

2. WHO Director-General's opening remarks at the media briefing on COVID19. (2020). Available at https://www.who.int/directorgeneral/speeches/detail/who-director-general-s-opening-remarks-at-themedia-briefing-on-covid-19 [June 2, 2021].

3. Krewski, D., Cameron, D. W., \& Wen, S. W. (2021). The Effects of Traditional Chinese Medicine as an Auxiliary Treatment for COVID-19: A Systematic Review and Meta-Analysis. Journal of alternative and complementary medicine (New York, N.Y.), 27(3), 225-237. https://doi.org/10.1089/acm.2020.0310

4. Yuan, H., Ma, Q., Ye, L., \& Piao, G. (2016). The Traditional Medicine and Modern Medicine from Natural Products. Molecules (Basel, Switzerland), 21(5), 559. https://doi.org/10.3390/molecules21050559

5. Green, A. Li Wenliang. (2020) Lancet.395(10225):659-754. DOI: https://doi.org/10.1016/S0140-6736(20)30382-2

6. Wang C., Horby P.W., Hayden F.G., Gao G.F. A novel coronavirus outbreak of global health concern. Lancet. 2020;395(10223):470-473.

7. Wu F., Zhao S., Yu B. A new coronavirus associated with human respiratory disease in China. Nature. 2020;579(7798):265-269.

8. Lu, R., Zhao, X., Li, J., Niu, P., Yang, B., Wu, H., Wang, W., Song, H., Huang, B., Zhu, N., Bi, Y., Ma, X., Zhan, F., Wang, L., Hu, T., Zhou, H., Hu, Z., Zhou, W., Zhao, L., Chen, J., ... Tan, W. (2020). Genomic characterisation and epidemiology of 2019 novel coronavirus: implications for virus origins and receptor binding. Lancet (London, England), 395(10224), 565-574. https://doi.org/10.1016/S0140-6736(20)30251-8

9. Zhang, T., Wu, Q., \& Zhang, Z. (2020). Probable Pangolin Origin of SARSCoV-2 Associated with the COVID-19 Outbreak. Current biology: CB, 30(7), 1346-1351.e2. https://doi.org/10.1016/j.cub.2020.03.022

10. WHO Novel coronavirus - Thailand (ex-China). Geneva: World Health Organization. (2020). Available at https://www.who.int/csr/don/14-january2020-novel-coronavirus-thailand/en/ [June 3,2021].

11. WHO Novel Coronavirus - Japan (ex-China). Geneva: World Health Organization. (2020). Available at https://www.who.int/csr/don/16-january2020-novel-coronavirus-japan-ex-china/en/ [June 4, 2021].

12. China National Health Commission Update on the novel coronavirus pneumonia outbreak. (2020). Beijing: China National Health Commission. Available

2020. http://www.nhc.gov.cn/xcs/yqfkdt/202001/c5da49c4c5bf4bcfb320ec2 036480627.shtml [June 1, 2021].

13. WHO Novel coronavirus - Republic of Korea (ex-China). Geneva: World Health Organization. (2020). Available at https://www.who.int/csr/don/21january-2020-novel-coronavirus-republic-of-korea-ex-china/en/ [June 3, 2021].

14. US Centers for Disease Control and Prevention First travel-related case of 2019 novel coronavirus detected in United States. Atlanta, GA: US Centers for Disease Control and Prevention. (2020). Available at https://www.cdc.gov/media/releases/2020/p0121-novel-coronavirustravel-case.html [June 3, 2021]. 
ISSN 2250-3153

15. Huang C, Wang Y, Li X.(2020). Clinical features of patients infected with 2019 novel coronavirus in Wuhan, China. Lancet. 2020 doi: 10.1016/S01406736(20)30183-5

16. Lee N, Hui D, Wu A, et. al. (2003). A major outbreak of severe acute respiratory syndrome in Hongkong. N Engl J Med.

17. Assiri A, Al-Tawfiq JA, Al-Rabeeeah AA, et.al. Epidemiological, demographic, and clinical characteristics of 47 cases of Middle East respiratory syndrome coronavirus disease from Saudi Arabia: a descriptive study. Lancet Infect Dis. 2013; 13: 752-761.

18. Mission summary: WHO Field Visit to Wuhan, China (2020). Available at https://www.who.int/china/news/detail/22-01-2020-field-visit-wuhan-chinajan-2020 [June 2, 2021].

19. Liu, Y., Ning, Z., Chen, Y., Guo, M., Liu, Y., Gali, N. K., Sun, L., Duan, Y., Cai, J., Westerdahl, D., Liu, X., Xu, K., Ho, K. F., Kan, H., Fu, Q., \& Lan, K. (2020). Aerodynamic analysis of SARS-CoV-2 in two Wuhan hospitals. Nature, 582(7813), 557-560. https://doi.org/10.1038/s41586-0202271-3

20. WHO Director-General's opening remarks at the media briefing on COVID19 (2020). Available at https://www.who.int/directorgeneral/speeches/detail/who-director-general-s-opening-remarks-at-themedia-briefing-on-covid-19---11-march-2020 [June 4,2020].

21. WHO Corona Virus situation report.(2020). Available https://www.who.int/docs/default-source/coronaviruse/situationreports/20201005-weekly-epi-update-8.pdf [June 4, 2021].

22. Xiang KY, Zu ZY, Lu GM, Zhang LJ. Coronavirus disease 2019 (COVID19): Chinese radiologists are acting. J Thorac Imaging. 2020 May 01; doi: 10.1097/RTI.0000000000000528.

23. Goudouris E. S. (2021). Laboratory diagnosis of COVID-19. Jornal de pediatria, 97(1), 7-12. https://doi.org/10.1016/j.jped.2020.08.001

24. SARS-CoV-2 Variant Classifications and Definitions. (2021). Available at https:/www.cdc.gov/coronavirus/2019-ncov/cases-updates/variantsurveillance/variant-info.html [June 4, 2021].

25. Center for Systems Science and Engineering, John Hopkins University. (2020). Available at https://github.com/CSSEGISandData/COVID-19 [June 5, 2021].

26. Max Roser, Hannah Ritchie, Esteban Ortiz-Ospina and Joe Hasell (2020) "Corona Virus Pandemic (COVID-19). Available at https://ourworldindata.org/coronavirus-data [June 2, 2021].

27. The New York Times COVID-19 updates. (2020). Available at https://www.nytimes.com/interactive/2021/us/covid-cases.html [June 04, 2021].

28. Ahmed I, Hasan M, Akter R, Sarkar BK, Rahman M, Sarker MS, Samad M. Behavioral preventive measures and the use of medicines and herbal products among the public in response to Covid-19 in Bangladesh: A cross-sectional study. (2020) PLOS ONE. Published: December 11, 2020 https://doi.org/10.1371/journal.pone.0243706.

29. Khanna, K., Kohli, S. K., Kaur, R., Bhardwaj, A., Bhardwaj, V., Ohri, P., Sharma, A., Ahmad, A., Bhardwaj, R., \& Ahmad, P. (2021). Herbal immuneboosters: Substantial warriors of pandemic Covid-19 battle. Phytomedicine: International journal of phytotherapy and phytopharmacology, 85, 153361. https://doi.org/10.1016/j.phymed.2020.153361

30. Amna Abdullah Alotiby, Laila Naif Al-Harbi. Prevalence of using herbs and natural products as a protective measure during the COVID-19 pandemic among the Saudi population: an online cross-sectional survey (2021) Saudi Pharmaceutical Journal. https://doi.org/10.1016/j.jsps.2021.04.001.

31. Hamulka J, Jeruszka-Bielak M, Górnicka M, Drywień ME, Zielinska-Pukos MA. Dietary Supplements during COVID-19 Outbreak. Results of Google Trends Analysis Supported by PLifeCOVID-19 Online Studies. Nutrients. 2021; 13(1):54. https://doi.org/10.3390/nu13010054

32. Ministry of AYUSH. COVID-19 related information: Ayurveda's immunity boosting measures for self-care during COVID 19 crisis. (2020). Available at https://www.ayush.gov.in/docs/123.pdf. [June 1, 2021].

33. Goothy S.S.K., Goothy S., Choudhary A., Potey G.G., Chakraborty H., Kumar A.H., Mahadik V.K. Ayurveda's holistic lifestyle approach for the management of coronavirus disease (COVID-19): possible role of tulsi. Int. J. Res. Pharm. Sci. 2020;11(SPL1):16-18.

34. Azis, SP, and Kaur, H. Enabling use of Homoeopathy in India's preparedness for pandemic/epidemic situation like COVID-19. Indian Journal of Research in Homeopathy 2020; 14(2):143-151 DOI: 10.4103/ijrh.ijrh_42_20

35. Ministry of AYUSH. Guidelines for Homeopathic Practitioners for COVID-19. (2020). https://www.ayush.gov.in/docs/homeopathy-guidelines.pdf. [June 2, 2021].

36. Ministry of AYUSH. Guidelines for SIDDHA Practitioners for COVID19. (2020). Availabe at https://www.ayush.gov.in/docs/siddhaguidelines.pdf. [June 3, 2021].

37. Natarajan, S., Anbarasi, C., Sathiyarajeswaran, P., Manickam, P., Geetha, S., Kathiravan, R., Prathiba, P., Pitchiahkumar, M., Parthiban, P., Kanakavalli, K., \& Balaji, P. (2020). The efficacy of Siddha Medicine, Kabasura Kudineer (KSK) compared to Vitamin C \& Zinc (CZ) supplementation in the management of asymptomatic COVID-19 cases: A structured summary of a study protocol for a randomised controlled trial. Trials, 21(1), 892. https://doi.org/10.1186/s13063-020-04823-z

38. Sabarianandh JV, Bernaitis L, Manimekalai K. COVID-19 in Siddha Medicine: A Review. J Basic Clin Appl Health Sci 2020;3(2):83-86. DOI: $10.5005 /$ jp-journals-10082-02256

39. Srivastava, A., Rengaraju, M., Srivastava, S., Narayan, V., Gupta, V., \& Upadhayay, R. (2021). A double blinded placebo controlled comparative clinical trial to evaluate the effectiveness of Siddha medicines, Kaba Sura Kudineer (KSK) \& Nilavembu Kudineer (NVK) along with standard Allopathy treatment in the management of symptomatic COVID 19 patients a structured summary of a study protocol for a randomized controlled trial. Trials, 22(1), 130. https://doi.org/10.1186/s13063-021-05041-X

40. Ransing, R., Pinto da Costa, M., Adiukwu, F., Grandinetti, P., Schuh Teixeira, A. L., Kilic, O., Soler-Vidal, J., \& Ramalho, R. (2020). Yoga for COVID-19 and natural disaster related mental health issues: Challenges and perspectives. Asian journal of psychiatry, 53, 102386. https://doi.org/10.1016/j.ajp.2020.102386

41. Ministry of AYUSH. Guidelines for Yoga Practitioners for COVID-19. https://www.ayush.gov.in/docs/yoga-guidelines.pdf

42. Ministry of AYUSH- Guidelines for Naturopathy Practitioners for COVID-19. https://www.ayush.gov.in/docs/naturopathy-guidelines.pdf 43. Ministry of AYUSH. Annexure-I Advisory from Ministry of AYUSH for meeting the challenge arising out of spread of corona virus (COVID19) in India. https://www.ayush.gov.in/docs/125.pdf. Accessed March $06,2020$.

44. Mekala P, Murthy K, Gopala TR (2020). Phytochemical screening and pharmacological update on Kabasura Kundineer CHoornam and Nilavembu Kundineer Choornam.JPharmacogn Phytochem:1 0311036: DOI: 10.22271/phyto.2020.v9.i3q.11428

45. Vikramkumar.V1, Ganesh.S2 , Sivanarul.M.P3 , Parthiban.P4 , Susikannamma.S 5 . Sivaraman.G6, Sathiyarajeswran.P.7 and Vinod.N. (2020) A data analysis observed on the preventive effect of Kabasura Kudineer among the facility-based quarantine high-risk contacts of COVID 19 - A cross-sectional study International Journal of Green and Herbal Chemistry: 10(1):055-061 DOI: 10.24214/IJGHC/HC/10/1/05561.

46. Savariar V, Selvaraj A, Muthupandian S, Manoj D. "Molecular Docking Studies on the Anti-viral Effects of Compounds From Kabasura Kudineer on SARS-CoV-2 3CLpro" (2020) Frontiers in Molecular Biosciences (7):434 DOI=10.3389/fmolb.2020.613401

47. Curran J. (2008). The Yellow Emperor's Classic of Internal Medicine. BMJ : British Medical Journal, 336(7647), 777. https://doi.org/10.1136/bmj.39527.472303.4E

48. Xiong Yibai, Li Na Xiao, Duan Naifang, Liu Bin, Zhu Hui, Zhang Chi, Li Li, Lu Cheng, Huang Luqi.(2020) Traditional Chinese Medicine in Treating Influenza: From Basic Science to Clinical Applications. Frontiers in Pharmacology 11,1376. DOI=10.3389/fphar.2020.575803 49. Bensky D. Chinese herbal medicine: formulas \& strategies. Seattle, Wash: Eastland Press, 1990.

50. Huang, K., Zhang, P., Zhang, Z., Youn, J. Y., Wang, C., Zhang, H., \& Cai, H. (2021). Traditional Chinese Medicine (TCM) in the treatment of COVID-19 and other viral infections: Efficacies and mechanisms. Pharmacology \& therapeutics, 225, 107843. Advance online publication. https://doi.org/10.1016/j.pharmthera.2021.107843

51. Capodice, J.L., Chubak, B.M. Traditional Chinese herbal medicine-potential therapeutic application for the treatment of COVID-19. Chin Med 16, 24 (2021). https://doi.org/10.1186/s13020-020-00419-6

52. Qing, G. C., Zhang, H., Bai, Y., \& Luo, Y. (2020). Traditional Chinese and Western Medicines Jointly Beat COVID-19 Pandemic. Chinese journal of integrative medicine, 26(6), 403-404. https://doi.org/10.1007/s11655-0203095-6

53. Wang J, Sasse A, Sheridan H. (2019) Traditional Chinese Medicine: From Aqueous Extracts to Therapeutic Formulae. DOI: 10.5772/intechopen.85733 
International Journal of Scientific and Research Publications, Volume 11, Issue 8, August 2021

ISSN 2250-3153

54. Xiao GL, Song K, Yuan CJ, et al. A literature report on the treatment of SARS

by stages with traditional Chinese medicine. J Emerg Chin Med

Hunan, 2005: 53-55.

This publication is licensed under Creative Commons Attribution CC BY. 